\title{
Uma reforma gerencial da Administração Pública no Brasil ${ }^{1}$
}

\author{
Luiz Carlos Bresser Pereira
}

\section{A reforma da Administração Pública}

A reforma do Estado, que se tornou tema central nos anos $90 \mathrm{em}$ todo o mundo, é uma resposta ao processo de globalização em curso, que reduziu a autonomia dos estados de formular e implementar políticas, e principalmente à crise do Estado, que começa a se delinear em quase todo o mundo nos anos 70, mas que só assume plena definição nos anos 80. No Brasil, a reforma do Estado começou nesse momento, em meio a uma grande crise econômica, que chega ao auge em 1990 com um episódio hiperinflacionário. A partir de então a reforma do Estado se torna imperiosa. Problemas considerados cruciais como o ajuste fiscal, a privatização e a abertura comercial, cujo ataque vinha sendo ensaiado nos anos anteriores, são, então, atacados de frente. A reforma administrativa, entretanto, só se tornou um tema central no Brasil em 1995, após a eleição e a posse de Fernando Henrique Cardoso. Nesse ano ficou claro para a sociedade brasileira que essa reforma tornara-se condição, de um lado, da consolidação do ajuste fiscal do Estado brasileiro, e, de outro, da existência no país de um serviço público moderno, profissional e eficiente, voltado para o atendimento das necessidades dos cidadãos.

A crise do Estado impôs a necessidade de reconstruí-lo; a globalização tornou imperativo redefinir suas funções. Antes da integração mundial dos mercados e dos sistemas produtivos, os Estados podiam ter como um de seus objetivos fundamentais proteger as respectivas economias da competição internacional. Depois da globalização, as possibilidades do Estado de continuar a exercer esse papel diminuíram muito. Seu novo

Ministro da
Administração
Federal e
Reforma do
Estado e
professor da
Fundação
Getúlio Vargas,
São Paulo 
papel é o de facilitar, para que a economia nacional se torne internacionalmente competitiva. A regulação e a intervenção continuam necessárias na educação, na saúde, na cultura, no desenvolvimento tecnológico, nos investimentos em infra-estrutura - uma intervenção que não apenas compense os desequilíbrios distributivos provocados pelo mercado globalizado, mas principalmente que capacite os agentes econômicos a competirem em nível mundial. ${ }^{2}$ No plano econômico a diferença entre uma proposta de reforma neoliberal e uma social-democrática ou socialliberal está no fato de que o objetivo da primeira é retirar o Estado da economia, enquanto que o da segunda é aumentar a governança do Estado, é dar ao Estado meios financeiros e administrativos para que ele possa intervir efetivamente sempre que o mercado não tiver condições de estimular a capacidade competitiva das empresas nacionais e de coordenar adequadamente a economia.

Embora o Estado seja, antes de mais nada, o reflexo da sociedade, vamos aqui pensá-lo como sujeito, não como objeto - como organismo cuja governança precisa ser ampliada para que possa agir mais efetiva e eficientemente em benefício da sociedade. Os problemas de governabilidade não decorrem de "excesso de democracia", do peso excessivo das demandas sociais, mas da falta de um pacto político ou de uma coalizão de classes que ocupe o centro do espectro político. ${ }^{3}$ Nosso pressuposto é de que o problema político da governabilidade foi provisoriamente equacionado com o retorno da democracia e a formação do "pacto democráticoreformista de 1994" possibilitada pelo êxito do Plano Real e pela eleição de Fernando Henrique Cardoso. ${ }^{4}$ Este pacto não resolveu definitivamente os problemas de governabilidade existentes no país, já que estes são por definição crônicos, mas deu ao governo condições políticas para ocupar o centro político e ideológico e, a partir de um amplo apoio popular, propor e implementar a reforma do Estado.

Por outro lado, no plano social, a diferença entre a proposta neoliberal e o novo Estado social-liberal que está surgindo está no fato de que os verdadeiros neoliberais querem a retirada do Estado também da área social. Criticam fortemente a intervenção do Estado social, que no Primeiro Mundo se manifestou como welfare state, porque esta intervenção mesmo na educação e na saúde acabaria sendo objeto de rentseeking por parte de grupos especiais de interesses, formados por empresários, por grupos de classe média, por funcionários, que assim privatizam a coisa pública. Adotando um individualismo radical e carente de realismo político, pretendem que a educação e a saúde, por mais importantes que possam ser, sejam problemas que as famílias e os indivíduos devam resolver e financiar. Entretanto, o resultado de tal crítica e da resposta social-democrática não é o Estado liberal (pregado pelo neo- 
conservadorismo), nem o Estado social-democrata (outro nome para o

Welfare State), mas o Estado social-liberal, que continua responsável pela proteção dos direitos sociais, mas que garante essa proteção deixando gradualmente de exercer de forma direta as funções de educação, saúde e assistência social para contratar organizações públicas nãoestatais para realizá-las. ${ }^{5}$

\section{Crise e reforma}

No Brasil, a percepção da natureza da crise e, em seguida, da necessidade imperiosa de reformar o Estado ocorreu de forma acidentada e contraditória, em meio ao desenrolar da própria crise. Entre 1979 e 1994 o Brasil viveu um período de estagnação da renda per capita e de alta inflação sem precedentes. Em 1994, finalmente, estabilizaram-se os preços através do Plano Real, criando-se as condições para a retomada do crescimento. A causa fundamental dessa crise econômica foi a crise do Estado - uma crise que ainda não está plenamente superada, apesar de todas as reformas já realizadas. Crise que se caracteriza pela perda de capacidade do Estado de coordenar o sistema econômico de forma complementar ao mercado. Coordenação econômica que envolve alocação de recursos, acumulação de capital e distribuição de renda. Em economias capitalistas esse papel é desempenhado pelo mercado e pelo Estado. Quando o Estado (ou o mercado) entra em crise, essa função fica seriamente prejudicada.

A crise do Estado, que se manifestou claramente nos anos 80, também pode ser definida: como uma crise fiscal, como uma crise do modo de intervenção do Estado, como uma crise da forma burocrática pela qual o Estado é administrado, e como uma crise política.

A crise política teve três momentos: primeiro, a crise do regime militar, entre 1977 e 1985 - uma crise de legitimidade; segundo, a tentativa populista (1985-1986) de voltar aos anos 50 - uma crise de adaptação ao regime democrático; e finalmente, a crise que levou ao impeachment de Fernando Collor de Mello - uma crise moral. A crise fiscal ou financeira caracterizou-se pela perda do crédito público e por poupança pública negativa. A crise do modo de intervenção, acelerada pelo processo de globalização da economia mundial, caracterizou-se pelo esgotamento do modelo protecionista de substituição de importações, que foi bem-sucedido em promover a industrialização nos anos de 30 a 50, mas que deixou de sê-lo a partir dos anos 60; transpareceu na falta de competitividade de uma parte ponderável das empresas brasileiras; expressou-se no fracasso de se criar no Brasil um Estado do Bem-Estar que se 
aproximasse dos moldes social-democratas europeus. Por fim, a crise da forma burocrática de administrar um Estado emergiu com toda a força depois da Constituição de 1988, antes mesmo que a própria administração pública burocrática pudesse ser plenamente instaurada no País.

A crise do modelo burocrático de administração pública, que foi introduzido no País nos anos 30, no governo Vargas, começou ainda no regime militar, devido a sua incapacidade de extirpar as práticas patrimonialistas ou clientelistas da administração. O regime militar foi capaz de criar agências burocráticas insuladas, mas elas co-existiram com o clientelismo e o corporativismo (NunEs, 1984). Ao invés de consolidar uma burocracia profissional no País, através da redefinição das carreiras e de um processo sistemático de abertura de concursos públicos para a alta administração, o regime militar preferiu o caminho mais curto do recrutamento de administradores através das empresas estatais. ${ }^{6}$ Esta estratégia oportunista do regime militar, que resolveu adotar a saída mais fácil da contratação de altos administradores através das empresas, inviabilizou a construção no País de uma burocracia civil forte, nos moldes que a reforma de 1936 propunha. A crise agravou-se, entretanto, a partir da Constituição de 1988, quando se salta para o extremo oposto e a administração pública brasileira passa a sofrer do mal oposto: o enrijecimento burocrático extremo. As conseqüências da sobrevivência do patrimonialismo e do enrijecimento burocrático, muitas vezes perversamente misturados, serão o alto custo e a baixa qualidade da administração pública brasileira. $^{7}$

A resposta da sociedade brasileira aos quatro aspectos da crise do Estado foi desequilibrada e ocorreu em momentos diferentes. A resposta à crise política foi a primeira: em 1985 o país completou sua transição democrática; em 1988, consolidou-a com a aprovação da nova Constituição. Já em relação aos outros três aspectos - a crise fiscal, o esgotamento do modo de intervenção e a crescente ineficiência do aparelho estatal o novo regime instalado no País em 1985 pouco ajudou. ${ }^{8}$ Pelo contrário, em um primeiro momento agravaram-se os problemas, constituindo-se em um caso clássico de resposta voltada para trás. Em relação à crise fiscal e ao modo de intervenção do Estado, as forças políticas vitoriosas tinham como parâmetro o desenvolvimentismo populista dos anos 50; em relação à administração pública, a visão burocrática dos anos 30 .

\section{Da administração burocrática à gerencial}

A administração burocrática clássica, baseada nos princípios da administração do Exército prussiano, foi implantada nos principais países europeus no final do século passado; nos Estados Unidos, no começo 
deste século; no Brasil, em 1936. Este modelo tem como fundamentos

um corpo profissional de funcionários, promoções baseadas em mérito e tempo de serviço e uma definição legal rígida de objetivos e meios para alcançá-los. No Brasil, embora tenham sido valorizados instrumentos importantes à época, tais como o instituto do concurso público e do treinamento sistemático, não se chegou a adotar consistentemente uma política de recursos humanos que respondesse às necessidades do Estado. Ainda que em processo de transformação, o patrimonialismo (contra o qual a administração pública burocrática se instalara) mantinha sua própria força no quadro político brasileiro. A expressão local do patrimonialismo - o coronelismo - dava lugar ao clientelismo e ao fisiologismo, e continuava a permear a administração do Estado brasileiro.

A administração pública burocrática foi adotada para substituir a administração patrimonialista, que definiu as monarquias absolutas, na qual o patrimônio público e o privado eram confundidos. $\mathrm{O}$ nepotismo e o empreguismo, senão a corrupção, eram a norma. Com a emergência do capitalismo e da democracia, tornou-se assim necessário desenvolver um tipo de administração que partisse não apenas da clara distinção entre o público e o privado, mas também da separação entre o político e o administrador público. Começa a tomar forma assim a administração burocrática moderna, racional-legal (nos termos de Weber); surge a organização burocrática, baseada na centralização das decisões, na hierarquia traduzida no princípio da unidade de comando, na estrutura piramidal do poder, nas rotinas rígidas, no controle passo a passo dos processos administrativos, em uma burocracia estatal formada por administradores profissionais especialmente recrutados e treinados, que respondem de forma neutra aos políticos. Max Weber (1922) definiu e descreveu de forma genial esse tipo de administração no início deste século.

Como a administração pública burocrática vinha combater o patrimonialismo e foi implantada no século XIX, no momento em que a democracia dava seus primeiros passos, era natural que desconfiasse de tudo e de todos — dos políticos, dos funcionários, dos cidadãos. Deveriam existir controles rigorosos e procedimentais. Eram preferíveis leis, regulações e rotinas severas em lugar de tomadas de decisão sempre que possível. Já a administração pública gerencial, sem ser ingênua, parte do pressuposto de que já chegamos num nível cultural e político em que o patrimonialismo está condenado, em que o burocratismo está excluído, porque é ineficiente, e em que é possível desenvolver estratégias administrativas baseadas na ampla delegação de autoridade e na cobrança $a$ posteriori de resultados.

Aos poucos foram-se delineando os contornos da nova administração pública ou administração pública gerencial em vários países, principalmente na Inglaterra, Nova Zelândia e Austrália: 
1) descentralização do ponto de vista político, transferindo recursos e atribuições para os níveis políticos regionais e locais;

2) descentralização administrativa, através da delegação de autoridade para os administradores públicos transformados em gerentes crescentemente autônomos;

3) organizações com poucos níveis hierárquicos ao invés de piramidal;

4) organizações flexíveis ao invés de unitárias e monolíticas, nas quais as idéias de multiplicidade, de competição administrada e de conflito tenham lugar;

5) pressuposto da confiança limitada e não da desconfiança total;

6) definição dos objetivos a serem atingidos pelas unidades descentralizadas na forma de indicadores de desempenho, sempre que possível quantitativos, que constituirão o centro do contrato de gestão entre o ministro e o responsável pelo órgão que está sendo transformado em agência;

7) controle por resultados, a posteriori, ao invés do controle rígido, passo a passo, dos processos administrativos; e

8) administração voltada para o atendimento do cidadão, ao invés de auto-referida.

Mais amplamente, a administração pública gerencial está baseada em uma concepção de Estado e de sociedade democrática e plural, enquanto que a administração pública burocrática tem um vezo centralizador e autoritário. Afinal o liberalismo do século XIX, no qual se moldou a forma burocrática de administração pública, era um regime político de transição do autoritarismo para a democracia. Enquanto a administração pública burocrática acredita em uma racionalidade absoluta, que a burocracia está encarregada de garantir, a administração pública gerencial pensa na sociedade como um campo de conflito, cooperação e incerteza, na qual cidadãos defendem seus interesses e afirmam suas posições ideológicas, que afinal se expressam na administração pública. Nestes termos, o problema não é o de alcançar a racionalidade perfeita, mas de definir instituições e práticas administrativas suficientemente abertas e transparentes de forma a garantir que o interesse coletivo na produção de bens públicos ou "quasi-publicos" pelo Estado seja razoavelmente atendido.

\section{As duas reformas administrativas}

No Brasil, a idéia de uma administração pública gerencial é antiga. Os princípios da administração burocrática clássica foram introduzidos no país através da criação, em 1936, do DASP — Departamento Administrativo do Serviço Público. ${ }^{9}$ A criação do DASP representou a primeira reforma administrativa do país. ${ }^{10}$ Entretanto, já em 1938, temos um primeiro 
sinal de administração pública gerencial, com a criação da primeira autarquia. Surgia, então, a idéia de que os serviços públicos que tinham funções executivas e não formuladoras de políticas — "administração indireta" - deveriam ser descentralizados e não obedecer a todos os requisitos burocráticos da "administração direta" ou central.

A primeira tentativa de reforma gerencial da administração pública brasileira, entretanto, irá acontecer no final dos anos 60, através do Decreto-Lei 200, de 1967, sob o comando de Amaral Peixoto e a inspiração de Hélio Beltrão, que iria ser o pioneiro das novas idéias no Brasil. ${ }^{11}$ A reforma iniciada pelo Decreto-Lei 200 foi uma tentativa de superação da rigidez burocrática, podendo ser considerada como um primeiro momento da administração gerencial no Brasil. Toda a ênfase foi dada à descentralização mediante a autonomia da administração indireta, a partir do pressuposto da rigidez da administração direta e da maior eficiência da administração descentralizada. ${ }^{12} \mathrm{O}$ decreto-lei promoveu a transferência das atividades de produção de bens e serviços para autarquias, fundações, empresas públicas e sociedades de economia mista, consagrando e racionalizando uma situação que já se delineava na prática. Instituíramse, como princípios de racionalidade administrativa, o planejamento e o orçamento, a descentralização e o controle dos resultados. Nas unidades descentralizadas foram utilizados empregados celetistas, submetidos ao regime privado de contratação de trabalho. O momento era de grande expansão das empresas estatais e das fundações. Através da flexibilização de sua administração, buscava-se uma maior eficiência nos serviços e nas atividades econômicas do Estado, e se fortalecia a aliança política entre os altos escalões da tecnoburocracia estatal, civil e militar e a classe empresarial. ${ }^{13}$

O Decreto-Lei 200 teve, entretanto, duas conseqüências inesperadas e indesejáveis. De um lado, ao permitir a contratação de empregados sem concurso público, facilitou a sobrevivência de práticas patrimonialistas e fisiológicas. De outro lado, ao não se preocupar com mudanças no âmbito da administração direta ou central, que foi vista pejorativamente como "burocrática" ou rígida, deixou de realizar concursos e de desenvolver carreiras de altos administradores. O núcleo estratégico do Estado foi, assim, enfraquecido indevidamente através de uma estratégia oportunista do regime militar, que, ao invés de se preocupar com a formação de administradores públicos de alto nível, selecionados através de concursos públicos, preferiu contratar os escalões superiores da administração através das empresas estatais. ${ }^{14}$

Desta maneira, a reforma administrativa embutida no Decreto-Lei 200 ficou pela metade e fracassou. A crise política do regime militar, que se inicia já em meados dos anos 70, agrava ainda mais a situação da 

identificada com o sistema autoritário em pleno processo de degeneração.

\section{A volta aos anos 50 e aos anos 30}

A transição democrática ocorrida com a eleição de Tancredo Neves e a posse de José Sarney, em março de 1985, não irá, entretanto, apresentar boas perspectivas de reforma do aparelho do Estado. Pelo contrário, significará no plano administrativo uma volta aos ideais burocráticos dos anos 30, e no plano político, uma tentativa de volta ao populismo dos anos 50 . Os dois partidos que comandam a transição eram partidos democráticos, mas populistas. Não tinham, como a sociedade brasileira também não tinha, a noção da gravidade da crise que o país estava atravessando. Havia, ainda, uma espécie de euforia democrático-populista, uma idéia de que seria possível voltar aos anos dourados da democracia e do desenvolvimento brasileiro, que foram os anos 50.

O capítulo da administração pública da Constituição de 1988 será o resultado de todas essas forças contraditórias. De um lado ela é uma reação ao populismo e ao fisiologismo que recrudesceram com o advento da democracia. ${ }^{15}$ Por isso a Constituição irá sacramentar os princípios de uma administração pública arcaica, burocrática ao extremo. Uma administração pública altamente centralizada, hierárquica e rígida, em que toda a prioridade será dada à administração direta ao invés da indireta. A Constituição de 1988 ignorou completamente as novas orientações da administração pública. Os constituintes e, mais amplamente, a sociedade brasileira revelaram nesse momento uma incrível falta de capacidade de ver o novo. Perceberam apenas que a administração burocrática clássica, que começara a ser implantada no país nos anos 30, não havia sido plenamente instaurada. Viram que o Estado havia adotado estratégias descentralizadoras - as autarquias e as fundações públicas - que não se enquadravam no modelo burocrático-profissional clássico. Notaram que essa descentralização havia aberto um certo espaço para o clientelismo, principalmente no nível dos estados e municípios — clientelismo esse que se acentuara após a redemocratização. Não perceberam que as formas mais descentralizadas e flexíveis de administração, que o Decreto-Lei 200 havia consagrado, eram uma resposta à necessidade de o Estado administrar com eficiência as empresas e os serviços sociais. E decidiram, primeiro, completar a revolução burocrática, para depois pensar nos princípios da moderna administração pública.

A partir dessa perspectiva, decidiram:

1) através da instauração de um "regime jurídico único" para todos os servidores públicos civis da administração pública direta e das autarquias e fundações tratar de forma igual faxineiros e juízes, professores e dele- 
gados de polícia, agentes de portaria e altos administradores públicos que exercem o poder de Estado;

2) através de uma estabilidade rígida, inviabilizar a cobrança de trabalho dos funcionários relapsos ou excedentes, ignorando que este instituto foi criado para defender o Estado, não os seus funcionários;

3) através de um sistema de concursos públicos ainda mais rígido, inviabilizar para que uma parte das novas vagas fossem abertas para funcionários já existentes;

4) através da extensão a toda a administração pública das novas regras, eliminar toda a autonomia das autarquias e fundações públicas;

5) através de uma série de dispositivos, criar um sistema de rigoroso privilégio para a aposentadoria dos servidores públicos e para seus pensionistas.

Desta forma, e contraditoriamente com seu espírito burocrático racional-legal, a Constituição de 1988 permitiu que uma série de privilégios fossem consolidados ou criados. Privilégios que foram ao mesmo tempo um tributo pago ao patrimonialismo ainda presente na sociedade brasileira, e uma conseqüência do corporativismo que recrudesceu com a abertura democrática, levando todos os atores sociais a defenderem seus interesses particulares como se fossem interesses gerais. O mais grave dos privilégios foi o estabelecimento de um sistema de aposentadoria com remuneração integral, sem nenhuma relação com o tempo de serviço prestado diretamente ao Estado. Este fato, mais a instituição de aposentadorias especiais, que permitiram aos servidores aposentarem-se muito cedo, em torno dos 50 anos, e, no caso dos professores universitários, de acumular aposentadorias, elevou violentamente o custo do sistema previdenciário estatal, representando um pesado ônus fiscal para a sociedade. ${ }^{16}$ Um segundo privilégio foi ter permitido que, de um golpe, mais de 400 mil funcionários celetistas das fundações e autarquias se transformassem em funcionários estatutários, detentores de estabilidade e aposentadoria integral. ${ }^{17}$

O retrocesso burocrático ocorrido em 1988 não pode ser atribuído a um suposto fracasso da descentralização e da flexibilização da administração pública que o Decreto-Lei 200 teria promovido. Embora alguns abusos tenham sido cometidos em seu nome, seja em termos de excessiva autonomia para as empresas estatais, seja em termos do uso patrimonialista das autarquias e fundações (onde não havia a exigência de processo seletivo público para a admissão de pessoal), não é correto afirmar que tais distorções possam ser imputadas como causas do fenômeno. Na verdade, o retrocesso foi o resultado, em primeiro lugar, de uma visão equivocada das forças democráticas que derrubaram o regime militar sobre a natureza da administração pública então vigente. À medida que, no Brasil, a transição democrática ocorreu em meio à crise do Estado, esta última foi equivo- 
cadamente identificada pelas forças democráticas como resultado, entre outros, do processo de descentralização que o regime militar procurara implantar. Em segundo lugar, foi a conseqüência da aliança política que essas forças foram levadas a celebrar no processo de transição democrática com grupos corporativos e clientelistas, enquanto o populismo econômico se tornava dominante. Em terceiro lugar, resultou do ressentimento da velha burocracia contra a forma pela qual a administração central fora tratada no regime militar: estava na hora de restabelecer a força do centro e a pureza do sistema burocrático. Essa visão burocrática concentrou-se na antiga SAF, que se tornou o centro da reação burocrática no País, não apenas contra uma administração pública moderna, mas a favor dos interesses corporativistas do funcionalismo. ${ }^{18}$ Finalmente, um quarto fator relaciona-se com a campanha pela desestatização que acompanhou toda a transição democrática. As estatais foram vistas como demasiadamente poderosas, o que levaram os constituintes a aumentar os controles burocráticos sobre as empresas estatais, que haviam ganhado grande autonomia graças ao Decreto-Lei 200.

Em síntese, o retrocesso burocrático da Constituição de 1988 foi uma reação ao clientelismo que dominou o país naqueles anos, mas também foi uma afirmação de privilégios corporativistas e patrimonialistas incompatíveis com o ethos burocrático. Foi, além disso, uma consequiência de uma atitude defensiva da alta burocracia, que, sentindo-se acuada, injustamente acusada, defendeu-se de forma irracional.

Estas circunstâncias contribuíram para o desprestígio da administração pública brasileira, não obstante o fato de que os administradores públicos brasileiros são majoritariamente competentes, honestos e dotados de espírito público. Estas qualidades, que eles demonstraram desde os anos 30, quando a administração pública profissional foi implantada no Brasil, foram um fator decisivo para o papel estratégico que o Estado jogou no desenvolvimento econômico brasileiro. A implantação da indústria de base nos anos 40 e 50, o ajuste nos anos 60, o desenvolvimento da infra-estrutura e a instalação da indústria de bens de capital, nos anos 70, de novo o ajuste e a reforma financeira nos anos 80, e a liberalização comercial nos anos 90 , não teriam sido possíveis se não fosse a competência e o espírito público da burocracia brasileira. ${ }^{19}$

\section{Os salários e a folha}

A inexistência de uma política remuneratória para os servidores públicos federais durante o período autoritário não foi corrigida no retorno à democracia. As distorções salariais, que já eram grandes, apenas se aprofundaram, enquanto o total de gastos, que aumentou durante o 
governo Sarney, foi violentamente reduzido pelo governo Collor, através de uma grande redução dos salários médios reais. No governo Itamar o nível de salários foi recuperado, ao mesmo tempo que o total de gastos com pessoal cresceu de forma explosiva. Conforme demonstra a Tabela 1, os salários, que haviam sido reduzidos para a metade entre 1989 e 1992, em 1995 voltaram para um nível superior ao pico anterior (1990). A partir do final de 1992 o governo procurou, através de um programa de “isonomia salarial”, corrigir as profundas distorções na remuneração dos servidores que se acumularam a partir da segunda metade dos anos 80 . Algumas correções foram realizadas, mas o principal resultado, entretanto, foi um forte aumento nos gastos com pessoal, que alcançaram um pico histórico em 1995, sem que as distorções fossem eliminadas.

Tabela 1: Remuneração média real dos servidores do Executivo $(1989=100)$

\begin{tabular}{l|c|c}
\hline & Índice PCC - nível superior & Índice ponderado* \\
\hline 1989 & 100 & 100.0 \\
1990 & 106 & 110 \\
1991 & 70 & 73 \\
1992 & 62 & 65 \\
1993 & 82 & 82 \\
1994 & 99 & 100 \\
1995 & 117 & 128 \\
1996 & 101 & 111 \\
$1997 * *$ & 99 & 109 \\
\hline
\end{tabular}

* Observação: O Índice Ponderado foi construído a partir do índice das principais carreiras ponderado pelo número de ocupantes de cada carreira. Foi destacado o índice do Nível Superior do PCC - Plano de Classificação de Cargos, porque essa é a carreira mais representativa do serviço público brasileiro.

** Estimativa baseada nos dados até mar/1997.

Fonte: Ministério da Administração Federal e Reforma do Estado.

$\mathrm{O}$ aumento das remunerações ocorrido no governo Itamar, somado a alguns aumentos adicionais realizados nos três primeiros meses do governo Fernando Henrique, provocou um violento aumento dos salários médios reais e uma explosão correspondente dos gastos totais com pessoal no governo federal. A Tabela 2 apresenta os principais dados a respeito da despesa global. Em 1995 o gasto com pessoal alcançou, em reais deflacionados, um pico absoluto: 44,7 bilhões de reais, importando em aumento de $30 \%$ real de 1994 para 1995. Essa porcentagem foi semelhante ao aumento do salário médio real ocorrido nas remunerações médias que aumentaram $28 \%$ no mesmo período. Em termos de participação da folha no PIB, porém, o pico continuou a ser em 1990, em conseqüência do aumento 
dos salários que o governo, que então se encerrava, concedeu aos servidores federais. Só em 1996 os salários e a folha de pagamento do governo ficaram sob controle, como pode ser observado nas tabelas 1 e 2.

Tabela 2: Gastos com pessoal federal (civil e militar)*

\begin{tabular}{l|c|c|c}
\hline & em R\$ bilhões & $\begin{array}{c}\text { Índice } \\
(\mathbf{1 9 8 7}=\mathbf{1 0 0})\end{array}$ & \% do PIB** \\
\hline 1987 & 18,9 & 100,0 & 3,18 \\
\hline 1988 & 23,2 & 122,7 & 3,91 \\
\hline 1989 & 28,7 & 151,6 & 4,68 \\
\hline 1990 & 33,1 & 115,3 & 5,63 \\
\hline 1991 & 27,1 & 143,3 & 4,6 \\
\hline 1992 & 22,1 & 116,7 & 3,78 \\
\hline 1993 & 29,8 & 157,7 & 4,9 \\
\hline 1994 & 34,4 & 181,9 & 5,35 \\
\hline 1995 & 44,7 & 236,3 & 6,68 \\
\hline 1996 & 43,0 & 227,0 & 6,22 \\
\hline $1997 * * *$ & 42,5 & 224,4 & \\
\hline
\end{tabular}

* Índice deflacionado pelo IGP-DI/FGV. Valores apurados pelo critério de competência.

** Sobre o valor estimado para 1997.

*** Valor acumulado entre março e fevereiro de 1997.

Os aumentos salariais realizados no governo Itamar não lograram reduzir as distorções salariais existentes no serviço público federal. Estas distorções podem ser avaliadas sob dois ângulos. De um lado temos os desequilíbrios em relação ao mercado de trabalho privado; de outro, os desequilíbrios internos, com alguns setores ganhando muito bem e outros muito mal.

Existe no país uma crença generalizada de que a remuneração dos servidores públicos é baixa. A verdade não é essa. Elas são baixas para alguns setores, altas para outros. A Tabela 3 baseia-se em uma comparação entre os salários do setor público e do setor privado, na qual foram confrontadas as remunerações de cargos com atribuições semelhantes nos dois mercados. Os resultados mostram que, enquanto os executivos e profissionais de nível superior recebem salários mais elevados no setor privado, os funcionários menos qualificados do setor público (como os que trabalham em atividades auxiliares da administração, digitação, estoques, manutenção, instalação, vigilância, portaria, limpeza e copa, entre outros) têm remuneração substancialmente maior do que no setor privado. Dessa forma o setor público corrige o forte desnivelamento existente entre os altos ordenados e os baixos salários 
do setor privado, um desnivelamento que explica boa parte da alta concentração de renda existente no país, mas, em contrapartida, o faz criando uma outra distorção: a incomunicabilidade entre os mercados público e privado de trabalho.

Tabela 3: Salários médios: setor público e privado (reais de maio de 1995)

\begin{tabular}{l|c|c|c}
\hline & $\begin{array}{c}\text { Salário médio: } \\
\text { setor privado }\end{array}$ & $\begin{array}{c}\text { Salário médio: } \\
\text { setor público }\end{array}$ & $\begin{array}{c}\text { Diferença } \\
\text { público/privado }\end{array}$ \\
\hline Cargos executivos & 7.080 & 5.736 & $-19 \%$ \\
Cargos de nível superior & 1.899 & 1.814 & $-5 \%$ \\
Cargos de nível técnico/médio & 926 & 899 & $-3 \%$ \\
Cargos operacionais & 437 & 635 & $45 \%$ \\
\hline
\end{tabular}

Fonte: MARE (1995): SIAPE (Sistema Integrado de Administração de Pessoal).

Por outro lado, internamente ao serviço público federal, encontramos também enormes disparidades entre as remunerações dentro do Estado: funcionários com qualificações muito semelhantes, que realizam tarefas parecidas, não obstante recebem remunerações muito diferentes. Estas distorções internas tiveram origem no regime militar, quando o serviço público foi relegado a segundo plano e a burocracia do Estado passou a ser recrutada através das empresas estatais. A consequiência foi uma forte redução dos salários dos servidores estatutários, que até hoje se reflete na baixa remuneração dos participantes no Plano de Classificação de Cargos, que então pretendia ser o sistema universal de carreira e remuneração dos servidores federais.

Para fugir dessa situação (ou o PCC), dois tipos de estratégias foram adotados: o Poder Judiciário, o Ministério Público e o Poder Legislativo, tornados fortemente autônomos do ponto de vista administrativo a partir de 1988, trataram de aumentar por conta própria, independentemente do Poder Executivo, sua remuneração. Por outro lado, no Poder Executivo, as categorias tradicionalmente mais poderosas — os procuradores, os delegados de polícia, os diplomatas, os auditoresfiscais - e as novas carreiras de administradores/economistas, criadas depois da abertura democrática — os analistas do Tesouro e do orçamento e os gestores governamentais - passaram a receber "gratificações de produtividade", que, na verdade, não era outra coisa senão uma estratégia de aumento de salário. Dado seu caráter ad hoc, estas duas estratégias, perfeitamente compreensíveis e até certo ponto necessárias, tiveram como resultado o aprofundamento das distorções no sistema remuneratório dos servidores. 
Finalmente, temos uma terceira origem das distorções do sistema remuneratório federal: as falhas da lei. Estas falhas expressam-se principalmente através de dois mecanismos: a possibilidade de "incorporações de vantagens temporárias", como "quintos", e a possibilidade de acumulação de cargos e seus respectivos proventos por servidores ativos e inativos. Estas incorporações de vantagens temporárias e as acumulações de cargos, habilmente manipuladas, permitiram que um número crescente de servidores passasse a ganhar altos salários, surgindo então a expressão "marajás" para identificar esses funcionários. A Constituição de 1988 procurou enfrentar o problema através de um "teto de salários", correspondente à maior remuneração em cada um dos poderes (ministros de Estado, deputados federais e senadores, e ministros do Supremo Tribunal Federal), mas a interpretação do Supremo Tribunal Federal, excluindo as vantagens pessoais do teto, tornou esse teto inefetivo. Em 1996, a expectativa dos governadores era a de que a emenda da administração pública lograsse definir com clareza o teto, terminando de vez com os "marajás".

Como já vimos na Tabela 2, os aumentos de salários concedidos durante o governo Itamar provocaram um enorme aumento na folha de pagamento do governo federal. A folha quase dobrou o seu valor em termos reais: de 22,1 bilhões de reais em 1992, subiu para 44,7 bilhões em 1995. Somente a partir de 1996, a folha de pagamento passou a estar sob controle, sendo reduzida para 43 bilhões de reais.

Esse crescimento da folha não se deveu ao aumento do número de funcionários. Dada a necessidade de ajuste fiscal, que ficou patente a partir de 1987, e dado o custo elevado que passou a representar a contratação de novos servidores públicos, os concursos públicos foram quase totalmente suspensos a partir de 1988, de forma que o número total de funcionários diminuiu. Na verdade, conforme pode ser observado pela Tabela 4, o número de funcionários ativos, que chegou a alcançar 713 mil em 1989, baixou para 567 mil em 1995, e 535 mil em 1997. Se considerados também os funcionários das empresas estatais, a queda foi ainda maior, dado o fato adicional das privatizações. 
Tabela 4: Evolução do número de servidores da União

\begin{tabular}{l|c|c}
\hline & Civis Estatutários* & União** \\
\hline 1988 & 705.548 & 1.442 .657 \\
\hline 1989 & 712.740 & 1.488 .608 \\
\hline 1990 & 628.305 & 1.338 .155 \\
\hline 1991 & 598.375 & 1.266 .495 \\
\hline 1992 & 620.870 & 1.284 .474 \\
\hline 1993 & 592.898 & 1.258 .181 \\
\hline 1994 & 583.020 & 1.197 .460 \\
\hline 1995 & 567.689 & 1.222 .236 \\
\hline 1996 & 563.708 & 1.098 .727 \\
\hline $1997 * * *$ & 535.431 & \\
\hline$* \quad$ Civis da adm. direta (Poder Executivo), autarquias e fundações. \\
$* *$ \\
Inclui, além dos civis estatutários, os funcionários das empresas estatais. \\
$* * * \quad$ Posição de março.
\end{tabular}

Fonte: Ministério da Administração Federal e Reforma do Estado (1995).

A explicação para o aumento da folha tem de ser encontrada no aumento dos salários a partir de 1993, e no custo crescente dos servidores inativos. O elevado valor das aposentadorias, mais altas do que o último salário da atividade em quase $20 \%$, quando em outros países os proventos da aposentadoria variam em torno de $70 \%$ do último salário, e o fato de os servidores poderem se aposentar muito cedo, levou a uma explosão do custo dos inativos. Os inativos e pensionistas, que já representavam $30 \%$ do custo da folha de pessoal em 1991/1993, passaram a representar $40 \%$ em 1995.

Por outro lado, é preciso considerar que o Brasil conta com provavelmente o mais generoso sistema previdenciário do mundo. Enquanto nos demais países a aposentadoria ocorre aos $60 \mathrm{ou}$, mais freqüentemente aos 65 anos, aqui ela ocorre, em média, aos 53, subindo para 56 anos quando não se consideram as aposentadorias proporcionais. Nos demais países, a porcentagem com que o funcionário se aposenta em relação a seu último salário varia de 50 a $75 \%$, ao passo que no Brasil era até recentemente de $120 \%$. Os trabalhadores rurais, que são os mais pobres, aposentam-se em média aos 63 anos com um salário mínimo. Os trabalhadores urbanos aposentam-se um pouco mais cedo, e com uma aposentadoria maior, mas muito distante das aposentadorias do setor público.

A Tabela 5 dá uma idéia do privilégio representado pelo atual sistema de aposentadorias do setor público, quando comparado com o do setor privado. $\mathrm{O}$ valor das aposentadorias dos funcionários do Legislativo é 21,7 vezes maior do que a aposentadoria dos beneficiários do 
INSS. No caso do Judiciário, 20,4 vezes, e do Executivo, 8,25 vezes. Como o número de funcionários dos dois primeiros poderes é pequeno, a média geral deve estar ainda na casa das 8 vezes. É certo que desde 1993 os servidores vêm contribuindo para seu sistema de previdência. Em média, contribuem com $11 \%$ do seu salário, sem limite de remuneração, enquanto que no caso do INSS a contribuição e o benefício estão limitados a 10 salários mínimos. Por isso, os servidores contribuem, em média, com mais do que os trabalhadores do setor privado. Os cálculos realizados, entretanto, mostram que sua contribuição média é apenas 3,4 vezes maior do que a contribuição média para o INSS, enquanto que o benefício é 8 vezes maior.

Tabela 5: Aposentadorias médias da União/INSS

\begin{tabular}{l|c|c}
\hline \multicolumn{2}{l|}{ Em salários mínimos } & Vezes \\
\hline INSS & 1,7 & 1,0 \\
Executivo & 14,0 & 8,25 \\
Legislativo & 36,8 & 21,7 \\
Judiciário & 34,7 & 20,4 \\
\hline
\end{tabular}

Fonte: Ministério da Administração Federal e Reforma do Estado e Ministério da Previdência Social.

\section{Objetivos}

A partir de 1995, com o governo Fernando Henrique, surge uma nova oportunidade para a reforma do Estado em geral, e, em particular, do aparelho do Estado e do seu pessoal. Esta reforma terá como objetivos: a curto prazo, facilitar o ajuste fiscal, particularmente nos estados e municípios, onde existe um claro problema de excesso de quadros; a médio prazo, tornar mais eficiente e moderna a administração pública, voltandoa para o atendimento aos cidadãos.

O ajuste fiscal será realizado principalmente através de: a) exoneração de funcionários por excesso de quadros; b) definição clara de teto remuneratório para os servidores; e c) através da modificação do sistema de aposentadorias, aumentando-se o tempo de serviço exigido, a idade mínima para aposentadoria, exigindo-se tempo mínimo de exercício no serviço público e tornando o valor da aposentadoria proporcional à contribuição. As três medidas exigirão mudança constitucional. Uma alternativa às dispensas por excesso de quadros, que provavelmente será muito usada, será o desenvolvimento de sistemas de exoneração ou desligamento voluntário. Nestes sistemas os administradores escolhem a população de 
funcionários passíveis de exoneração e propõem que uma parte deles se exonere voluntariamente em troca de indenização e treinamento para a vida privada. Diante da possibilidade iminente de dispensa e das vantagens oferecidas para o desligamento voluntário, um número substancial de servidores se apresentará. ${ }^{20}$

Já a modernização ou o aumento da eficiência da administração pública será o resultado a médio prazo de um complexo projeto de reforma, através do qual se buscará a um só tempo fortalecer a administração pública direta ou o "núcleo estratégico do Estado", e descentralizar a administração pública através da implantação de "agências executivas" e de "organizações sociais" controladas por contratos de gestão. Nestes termos, a reforma proposta não pode ser classificada como centralizadora, como foi a de 1936, ou descentralizadora, como pretendeu ser a de 1967. Nem, novamente, centralizadora, como foi a contra-reforma embutida na Constituição de 1988. Em outras palavras, a proposta não é a de continuar no processo cíclico que caracterizou a administração pública brasileira, alternando períodos de centralização e de descentralização, mas a de, ao mesmo tempo, fortalecer a competência administrativa do centro e a autonomia das agências executivas e das organizações sociais. O elo de ligação entre os dois sistemas será o contrato de gestão, que o núcleo estratégico deverá aprender a definir e controlar, e as agências e organizações sociais, a executar. ${ }^{21}$

\section{Setores do Estado}

A proposta de reforma do aparelho do Estado parte da existência de quatro setores dentro do Estado:

1) o núcleo estratégico do Estado;

2) as atividades exclusivas de Estado;

3) os serviços não-exclusivos ou competitivos e

4) a produção de bens e serviços para o mercado.

No núcleo estratégico são definidas as leis e políticas públicas. É um setor relativamente pequeno, formado no Brasil, em nível federal, pelo Presidente da República, pelos ministros de Estado e a cúpula dos ministérios, responsáveis pela definição das políticas públicas, pelos tribunais federais encabeçados pelo Supremo Tribunal Federal e pelo Ministério Público e pelos congressistas. Em nível estadual e municipal existem correspondentes núcleos estratégicos.

As atividades exclusivas de Estado são aquelas em que o "poder de Estado", ou seja, o poder de legislar e tributar é exercido. Inclui a polícia, as Forças Armadas, os órgãos de fiscalização e de regulamentação, e os órgãos responsáveis pelas transferências de recursos para as áreas 
sociais e científicas, como o Sistema Unificado de Saúde, o sistema de auxílio-desemprego, etc.

Os serviços não-exclusivos ou competitivos do Estado são aqueles que, embora não envolvendo poder de Estado, o Estado realiza e/ou subsidia porque os considera de alta relevância para os direitos humanos, ou porque envolvem economias externas, não podendo ser adequadamente recompensados no mercado através da cobrança dos serviços. Os serviços sociais e científicos, como escolas, universidades, hospitais, museus, centros de pesquisa, instituições de assistência social, etc, fariam parte desse setor.

Finalmente, a produção de bens e serviços para o mercado é realizada pelo Estado através das empresas de economia mista, que operam em setores de serviços públicos e/ou em setores considerados estratégicos.

Em cada um desses setores será necessário considerar:

1) qual o tipo de propriedade e

2) qual o tipo de administração pública mais adequada e

3) qual o tipo de instituição seria mais apropriada.

A Figura 1 resume as relações entre essas variáveis.

Figura 1: Setores do Estado, forma de propriedade e administração e instituições

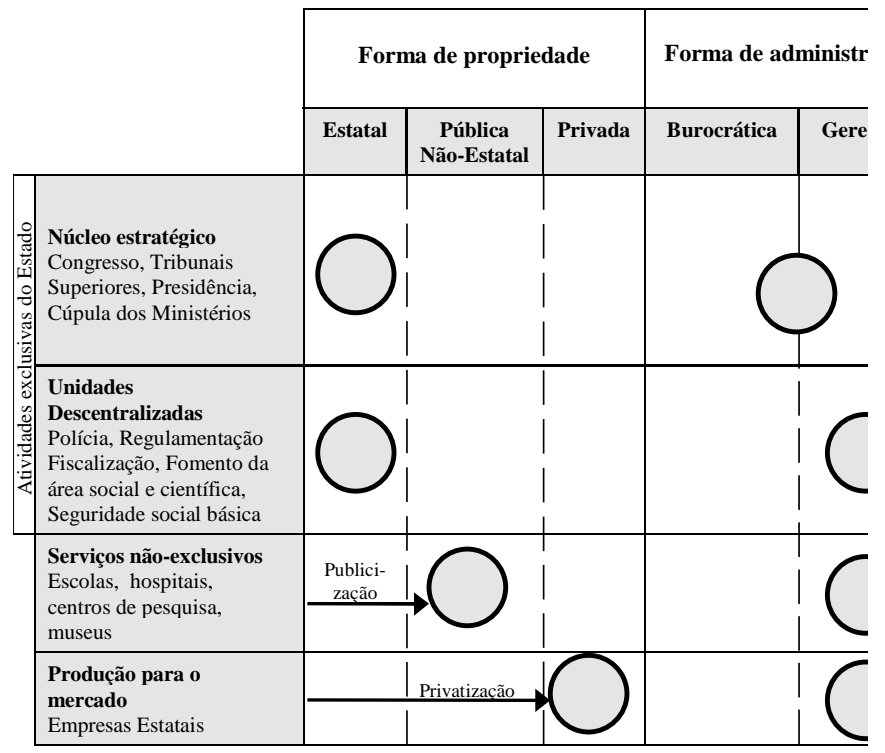

Fonte: Ministério da Administração Federal e Reforma do Estado (1995). Plano Diretor da Reforma do Estado.

No núcleo estratégico e nas atividades exclusivas de Estado a propriedade deverá ser, por definição, estatal. O núcleo estratégico usará, além dos instrumentos tradicionais — aprovação de leis (Congresso), definição de políticas públicas (Presidência e cúpula dos ministérios) e emissão 
de sentenças e acórdãos (Poder Judiciário) — de um novo instrumento,

que só recentemente vem sendo utilizado pela administração pública: o contrato de gestão. Através do contrato de gestão, o núcleo estratégico definirá os objetivos das entidades executoras do Estado e os respectivos indicadores de desempenho, e garantirá a essas entidades os meios humanos, materiais e financeiros para sua consecução.

Esta reforma é mais institucional do que organizacional e de gestão. Não se limita a propor reestruturação e introdução de modernas técnicas de gestão. Novas instituições são fundamentais para a reforma do Estado. As instituições descentralizadas serão, respectivamente, as "agências executivas", no setor das atividades exclusivas de Estado, e as "organizações sociais" nas atividades sociais e científicas, que são não-exclusivas de Estado.

As atividades exclusivas de Estado deverão ser, em princípio, organizadas através do sistema de "agências executivas", que poderíamos também chamar de "agências autônomas". 22 Uma agência executiva deverá ter um dirigente nomeado pelo respectivo ministro, com o qual será negociado o contrato de gestão. Uma vez estabelecidos os objetivos e os indicadores de desempenho não apenas qualitativos mas também quantitativos, o dirigente terá ampla liberdade para gerir o orçamento global recebido; poderá administrar seus funcionários com autonomia no que diz respeito à admissão, demissão e pagamento; e poderá realizar compras apenas obedecendo aos princípios gerais de licitação.

No outro extremo, no setor de bens e serviços para o mercado, a produção deverá ser em princípio realizada pelo setor privado. Daí o programa de privatização em curso. Pressupõe-se que as empresas serão mais eficientes se controladas pelo mercado e administradas privadamente. Daí deriva o princípio da subsidiariedade: só deve ser estatal a atividade que não puder ser controlada pelo mercado. Além disso, a crise fiscal do Estado retirou-lhe capacidade de realizar poupança forçada e investir nas empresas estatais, tornando-se aconselhável privatizá-las. Esta política está de acordo com a concepção de que o Estado moderno, que prevalecerá no século XXI, não será nem o Estado liberal, que se aproxima do mínimo, do século XIX, nem o Estado executor do século XX: deverá ser um Estado regulador e transferidor de recursos, que garante o financiamento a fundo perdido das atividades que o mercado não tem condições de realizar.

\section{Propriedade pública não-estatal}

Finalmente devemos analisar o caso das atividades não-exclusivas de Estado nos setores sociais e científicos. Nossa proposta é que a forma de propriedade dominante deverá ser a pública não-estatal. 
No capitalismo contemporâneo as formas de propriedade relevantes não são apenas duas, como geralmente se pensa, e como a divisão clássica do Direito entre Direito Público e Privado sugere - a propriedade privada e a pública —, mas são três:

1) a propriedade privada, voltada para a realização de lucro (empresas) ou de consumo privado (famílias);

2) a propriedade pública estatal; e

3) a propriedade pública não-estatal, que também pode ser chamada de não-governamental, não voltada para o lucro, ou propriedade do terceiro setor. A confusão deriva da divisão bipartite do Direito. Os tipos de propriedade e as suas correspondentes organizações são geralmente definidos de acordo com a lei que os regulam (Direito Público ou Privado), e não pelos seus objetivos. Conforme os objetivos, uma organização é privada quando orientada para o lucro, é pública quando orientada para o interesse público. Em termos legais uma organização é privada quando é propriedade privada de indivíduos, tais como são empresas e mesmo cooperativas; e é pública quando pertence à comunidade, à população. ${ }^{23}$

Com isto estou afirmando que o público não se confunde com o estatal. O espaço público é mais amplo do que o estatal, já que pode ser estatal ou não-estatal. No plano do dever-ser o estatal é sempre público, mas na prática não é: o Estado pré-capitalista era, em última análise, privado, já que existia para atender às necessidades do príncipe; no mundo contemporâneo o público foi conceitualmente separado do privado, mas vemos todos os dias as tentativas de apropriação privada do Estado.

É pública a propriedade que é de todos e para todos. É estatal a instituição que detém o poder de legislar e tributar, é estatal a propriedade que faz parte integrante do aparelho do Estado, sendo regida pelo Direito Administrativo. ${ }^{24}$ É privada a propriedade que se volta para o lucro ou para o consumo dos indivíduos ou dos grupos. De acordo com essa concepção, uma fundação “de Direito Privado", embora regida pelo Direito Civil, como são, por exemplo, as universidades americanas, é uma instituição pública, à medida que está voltada para o interesse geral. ${ }^{25} \mathrm{Em}$ princípio todas as organizações sem fins lucrativos são ou devem ser organizações públicas não-estatais. ${ }^{26}$ Sem dúvida poderíamos dizer que, afinal, continuamos apenas com as duas formas clássicas de propriedade: a pública e a privada, mas com duas importantes ressalvas: primeiro, a propriedade pública se subdivide em estatal e não-estatal ao invés de se confundir com a estatal; e segundo, as instituições de Direito Privado voltadas para o interesse público e não para o consumo privado não são privadas, mas públicas não-estatais. O reconhecimento de um espaço público não-estatal tornou-se particularmente importante em um momento em que a crise do Estado aprofundou a dicotomia Estado-setor privado, levando muitos a imaginar que a única alternativa à propriedade estatal é 
a privada. A privatização é uma alternativa adequada quando a instituição

pode gerar todas as suas receitas da venda de seus produtos e serviços, e o mercado tem condições de assumir a coordenação de suas atividades. Quando isto não acontece, está aberto o espaço para o público não-estatal. Por outro lado, no momento em que a crise do Estado exige o reexame das relações Estado-sociedade, o espaço público não-estatal pode ter um papel de intermediação ou pode facilitar o aparecimento de formas de controle social direto e de parceria, que abrem novas perspectivas para a democracia. Conforme observa Cunil Grau (1995: 31-32):

“A introdução do 'público' como uma terceira dimensão, que supera a visão dicotômica que enfrenta de maneira absoluta o 'estatal' com o 'privado', está indiscutivelmente vinculada à necessidade de redefinir as relações entre Estado e sociedade... O público, 'no Estado' não é um dado definitivo, mas um processo de construção, que por sua vez supõe a ativação da esfera pública social em sua tarefa de influir sobre as decisões estatais".

No setor dos serviços não-exclusivos de Estado, a propriedade deverá ser em princípio pública não-estatal. Não deve ser estatal porque não envolve o uso do poder-de-Estado. E não deve ser privada porque pressupõe transferências do Estado. Deve ser pública para justificar os subsídios recebidos do Estado. O fato de ser pública não-estatal, por sua vez, implicará na necessidade da atividade ser controlada de forma mista pelo mercado, pelo Estado, e principalmente pela sociedade. O controle do Estado, entretanto, será necessariamente antecedido e complementado pelo controle social direto, derivado do poder dos conselhos de administração constituídos pela sociedade. E o controle do mercado se materializará na cobrança dos serviços. Desta forma a sociedade estará permanentemente atestando a validade dos serviços prestados, ao mesmo tempo que se estabelecerá um sistema de parceria ou de co-gestão entre o Estado e a sociedade civil.

$\mathrm{Na}$ União, os serviços não-exclusivos de Estado mais relevantes são as universidades, as escolas técnicas, os centros de pesquisa, os hospitais e os museus. A reforma proposta é a de transformá-los em um tipo especial de entidade não-estatal, as organizações sociais. A idéia é transformá-los, voluntariamente, em "organizações sociais", ou seja, em entidades que celebrem um contrato de gestão com o Poder Executivo e contem com autorização do parlamento para participar do orçamento público. Organização social não é, na verdade, um tipo de entidade pública não-estatal, mas uma qualidade dessas entidades, declarada pelo Estado.

$\mathrm{O}$ aumento da esfera pública não-estatal aqui proposto não significa em absoluto a privatização de atividades do Estado. Ao contrário, 
trata-se de ampliar o caráter democrático e participativo da esfera pública, subordinada a um direito público renovado e ampliado. Conforme observa Tarso Genro (1996):

"A reação social causada pela exclusão, pela fragmentação, a emergência de novos modos de vida comunitária (que buscam na influência sobre o Estado o resgate da cidadania e da dignidade social do grupo) fazem surgir uma nova esfera pública não-estatal... Surge, então, um novo Direito Público como resposta à impotência do Estado e dos seus mecanismos de representação política. Um Direito Público cujas regras são às vezes formalizadas, outras não, mas que ensejam um processo cogestionário, que combina democracia direta — de participação voluntária — com a representação política prevista pelas normas escritas oriundas da vontade estatal".

A transformação dos serviços não-exclusivos de Estado em propriedade pública não-estatal e sua declaração como organização social se fará através de um "programa de publicização", que não deve ser confundido com o programa de privatização, à medida que as novas entidades conservarão seu caráter público e seu financiamento pelo Estado. O processo de publicização deverá assegurar o caráter público mas de direito privado da nova entidade, assegurando-lhes, assim, uma autonomia administrativa e financeira maior. Para isto será necessário extinguir as atuais entidades e substituí-las por fundações públicas de direito privado, criadas por pessoas físicas. Desta forma se evitará que as organizações sociais sejam consideradas entidades estatais, como aconteceu com as fundações de direito privado instituídas pelo Estado, e assim submetidas a todas as restrições da administração estatal. ${ }^{27}$ As novas entidades receberão por cessão precária os bens da entidade extinta. Os atuais servidores da entidade transformar-se-ão em uma categoria em extinção e ficarão à disposição da nova entidade. $\mathrm{O}$ orçamento da organização social será global; a contratação de novos empregados será pelo regime da Consolidação das Leis do Trabalho; as compras deverão estar subordinadas aos princípios da licitação pública, mas poderão ter regime próprio. $\mathrm{O}$ controle dos recursos estatais postos à disposição da organização social será feito através de contrato de gestão, além de estar submetido à supervisão do órgão de controle interno e do Tribunal de Contas.

Organizações sociais serão organizações públicas não-estatais mais especificamente fundações de direito privado - que celebram contrato de gestão com o Poder Executivo, com aprovação do Poder Legislativo, e, assim, ganham o direito de fazer parte do orçamento público federal, estadual ou municipal. A autonomia da organização social corresponderá a uma maior responsabilidade de seus gestores. Por outro 
lado, a idéia implica em um maior controle social e em uma maior parceria com a sociedade, já que o Estado deixa de diretamente dirigir a instituição.

No processo de "publicização" — transformação de entidades estatais de serviço em entidades públicas não-estatais - o importante é evitar a privatização e a feudalização das organizações sociais, ou seja, a apropriação destas por grupos de indivíduos que as usam como se fossem privadas. Feudalização ocorre quando esse grupo, embora orientado para o interesse público, perpetua-se no controle da organização, independentemente da sua capacidade gerencial.

\section{A reforma constitucional}

A reforma mais importante, porque dela depende a maioria das outras, é naturalmente a constitucional. Além de seu significado administrativo, ela tem um conteúdo político evidente. À medida que suas principais propostas - a flexibilização da estabilidade, o fim do Regime Jurídico Único, o fim da isonomia como preceito constitucional, o reforço dos tetos salariais, a definição de um sistema de remuneração mais claro, a exigência de projeto de lei para aumentos de remuneração nos três poderes - são aprovadas, não apenas abre-se espaço para a administração pública gerencial, mas também a sociedade e seus representantes políticos sinalizam seu compromisso com uma administração pública renovada, com um novo Estado moderno e eficiente.

O sistema atual é rígido, todos os funcionários têm estabilidade, a qual só pode ser rompida através de um processo administrativo em que se prove falta grave. A enumeração das faltas que podem ser consideradas é ampla, incluindo a desídia. Na verdade, entretanto, alguém só é demitido se furtou, se ofendeu grave e publicamente, ou se abandonou o emprego. Se isto aconteceu e puder ser provado, o funcionário poderá ser demitido sem nenhum direito. Nos demais casos, seja porque é difícil de provar, seja porque há uma cumplicidade generalizada que inviabiliza a demissão, ninguém é demitido. Na proposta de reforma o governo abandonou esse "tudo ou nada", segundo o qual ou o servidor conserva o emprego ou perde todos os seus direitos, e partiu para um sistema gradualista, semelhante ao já adotado pelo setor privado. São criadas duas novas causas para demissão, além da falta grave: a demissão por insuficiência de desempenho e a exoneração por excesso de quadros. Para ficar claro que a demissão por insuficiência de desempenho não é a mesma coisa que falta grave, o funcionário terá direito a uma pequena indenização. Esta indenização será maior se o desligamento tiver como causa o excesso de quadros, já que nesse caso não há responsabilidade pessoal do funcionário pelo fato de ter sido exonerado. 
A demissão por insuficiência de desempenho se dará caso a caso. Seu objetivo será permitir que o administrador público possa cobrar trabalho do funcionário e assim viabilizar a administração pública gerencial. Já o desligamento por excesso de quadros será impessoal e voltado para a demissão de grupos de funcionários. O objetivo é reduzir custos, é garantir que os contribuintes não sejam obrigados a pagar por funcionários para os quais o Estado não tenha necessidade. No segundo caso a indenização corresponderá, em princípio, a um salário por ano trabalhado, no primeiro, à metade desse valor.

O servidor só poderá ser demitido por insuficiência de desempenho se for submetido a processo de avaliação formal, e terá sempre direito a processo administrativo com ampla defesa. Este dispositivo visa permitir a cobrança de trabalho pelos administradores públicos. A motivação dos servidores deve ser principalmente positiva — baseada no sentido de missão, nas oportunidades de promoção e no reconhecimento salarial —, mas é essencial que haja também a possibilidade de punição. Já a exoneração por excesso de quadros permitirá a redução do déficit público, através da adequação do número de funcionários às reais necessidades da administração. A decisão deverá ser rigorosamente impessoal, obedecendo a critérios gerais (p.ex., os mais jovens, ou os mais recentemente admitidos sem dependentes), de forma a evitar a perseguição política. Os critérios impessoais evitarão longas contestações na Justiça, porque tornarão impossível a demissão de funcionários escolhidos pelos chefes de acordo com critérios em que sempre haveria um certo grau de subjetividade.

Uma alternativa seria combinar os critérios impessoais com avaliação de desempenho. Embora essa alternativa seja atrativa, ela é, na verdade, incompatível com o desligamento por excesso de quadros, que acabaria reduzido à demissão por insuficiência de desempenho. Todos os funcionários atingidos imediatamente argüiriam que estavam sendo vítimas de perseguição política, iniciar-se-ia uma longa ação judicial, e os objetivos da exoneração - reduzir quadros e despesa - seriam frustrados. De acordo com a proposta do governo, uma vez decidida a exoneração de um determinado número de servidores, os respectivos cargos serão automaticamente extintos, não podendo ser recriados dentro de quatro anos. Dessa forma evita-se a exoneração por motivos políticos.

Estas mudanças não se fazem apenas para atender o interesse público e o da cidadania, mas também em benefício do funcionário. Todo servidor competente e trabalhador, que valoriza seu próprio trabalho, será beneficiado. Saberá que está realizando uma tarefa necessária. E, ao mesmo tempo, readquirirá o respeito da sociedade — um respeito que foi perdido quando uma minoria de funcionários desinteressados, cujo trabalho não pode ser cobrado, estabeleceu padrões de ineficiência e mau atendimento para todo o funcionalismo. 
É importante, entretanto, observar que a estabilidade do servidor, embora flexibilizada, é mantida, na medida em que este só poderá ser demitido nos termos da lei. Caso haja algum abuso, poderá sempre ser reintegrado pela Justiça, ao contrário do que acontece no setor privado, onde não existe estabilidade, e o empregado demitido tem apenas direito à indenização. A manutenção da estabilidade do servidor não apenas reconhece o caráter diferenciado da administração pública em relação à administração privada, mas também a maior necessidade de segurança que caracteriza em todo o mundo os trabalhos dos servidores públicos. Estes tendem a ter uma vocação para o serviço público, estão dispostos a ter uma vida modesta, mas em compensação esperam maior segurança. Uma segurança maior, por exemplo, do que a dos políticos ou dos empresários. Esta segurança, entretanto, não pode ser absoluta. O Estado garante estabilidade aos servidores porque assim assegura maior autonomia ou independência à sua atividade pública, ao exercício do poder-de-Estado de que estão investidos; não a garante para atender a uma necessidade extremada de segurança pessoal, muito menos para inviabilizar a cobrança de trabalho, ou para justificar a perpetuação de excesso de quadros.

\section{Previdência pública}

A reforma do sistema de previdência do servidor público, por sua vez, é fundamental, na medida em que é a condição para a definitiva superação da crise fiscal do Estado. A crise do sistema previdenciário brasileiro deriva, em última análise, de uma concepção equivocada do que seja aposentadoria. Um sistema de pensões existe para garantir uma aposentadoria digna a quem chegou à velhice e não pode mais trabalhar; não existe para garantir um segundo salário a indivíduos ainda com grande capacidade de trabalho, não existe para aposentar pessoas, particularmente funcionários públicos, aos 50 anos de idade.

Os sistemas de aposentadoria garantidos pelo Estado, em todo mundo, não são sistemas de capitalização, mas, em princípio, sistemas de repartição, em que os funcionários ativos pagam a aposentadoria dos inativos. Esta preferência pelo sistema de repartição ocorre porque o Estado, que geralmente tem condições de garantir o sistema, é mau gestor de fundos de capitalização. Um sistema de capitalização, por outro lado, só é legítimo quando o participante do fundo depender efetivamente da rentabilidade do mesmo. Ora, é difícil senão impossível dizer aos funcionários que sua aposentadoria dependerá de quão bem o Estado administrará o possível fundo de capitalização. De acordo com o sistema de repartição, entretanto, é preciso que haja um equilíbrio entre o número de jovens, que pagam o sistema em termos correntes, e o número de velhos beneficiados pela aposentadoria. 
No Brasil estabeleceu-se um sistema de privilégios no que diz respeito ao sistema de aposentadorias dos servidores públicos, que se expressa na existência de aposentadoria integral independentemente da contribuição, e na possibilidade de se aposentar muito cedo. Enquanto os trabalhadores mais pobres do setor privado rural aposentam-se em média aos 62 anos, os funcionários públicos podem aposentar-se com proventos integrais em uma idade pouco superior aos 50 anos, e os altos funcionários, antes dos 50 anos! Por outro lado, o benefício médio do aposentado pela União é 8,1 vezes maior do que o benefício do aposentado do INSS, enquanto que a contribuição média do servidor público federal é 3,4 vezes maior do que a dos segurados no INSS.

O sistema previdenciário privado vem mantendo através dos anos um relativo equilíbrio financeiro devido à estrutura etária em forma de pirâmide achatada que ainda prevalece no País. Com a redução da taxa de natalidade, porém, essa estrutura etária está se modificando aceleradamente. Por isso a crise financeira da previdência já está aí. Uma crise que tenderá a agravar-se à medida que a relação entre os jovens, que têm de pagar os custos da previdência, e os aposentados for diminuindo. Nos anos 50 essa relação era de 8 para 1; hoje é de 2 para 1; em breve será de 1 para 1 e o sistema estará inviabilizado.

No caso da previdência pública, o desequilíbrio já é total: as contribuições dos funcionários somadas a uma virtual contribuição em dobro do Estado financiam cerca de um quinto do custo anual da folha de inativos e pensionistas. No entanto, o sistema sobrevive porque o Tesouro paga a diferença. Esta, entretanto, é uma situação iníqua - afinal os contribuintes estão pagando para que os funcionários se aposentem de forma privilegiada — que se tornou insustentável do ponto de vista fiscal: o sistema de aposentadorias do funcionalismo público provoca um rombo anual nas finanças públicas correspondente a quase $2 \%$ do PIB.

Para se sanar a médio prazo (a curto é impossível) esse desequilíbrio originado em um sistema de privilégios, as duas regras gerais que estão sendo previstas para a previdência privada deverão também ser rigorosamente aplicadas à previdência pública:

1) a aposentadoria deverá ser por idade, ligeiramente corrigida por tempo de serviço, de forma que os funcionários se aposentem em torno dos 60 anos, dez anos mais tarde do que hoje acontece; e

2) o valor da aposentadoria, baseado nas últimas remunerações recebidas, deverá ser proporcional à contribuição e não integral, como prevê a Constituição de 1988.

Só assim será possível garantir um custo razoável para o sistema previdenciário público. Este, entretanto, deverá permanecer garantido pelo Estado. Não faz sentido exigir de funcionários do Estado - uma institui- 
ção que, ao contrário das empresas privadas, tem condições de garantir um sistema previdenciário - , que recorram obrigatoriamente aos fundos privados de previdência complementar. O Estado garantirá a aposentadoria de seus servidores, independentemente do regime jurídico em que estiverem enquadrados. Para calcular quanto o funcionário deverá receber ao aposentar-se, deverá ser feito um cálculo atuarial. Dada a contribuição dos funcionários (em torno de $11 \%$ dos salários) e do Estado para a aposentadoria, dadas as idades médias em que o funcionário começa a contribuir, aposenta-se e falece, e dado um retorno razoável do fundo virtual (já que o sistema deverá ser de repartição), será possível calcular e estabelecer em lei a proporção da média dos últimos salários do funcionário que constituirá sua aposentadoria. Cálculos iniciais sugerem que essa porcentagem deverá girar em torno de $80 \%$.

Os direitos adquiridos e as expectativas de direitos serão plenamente respeitadas. Os funcionários que, antes da mudança da Constituição, já têm o direito de aposentar-se, aposentar-se-ão segundo as normas atuais, mesmo que decidam fazê-lo daqui a muitos anos, quando chegarem na idade compulsória. Este é um direito adquirido. Por outro lado, as expectativas de direito serão garantidas de forma proporcional. Um funcionário, por exemplo, que começou a trabalhar com 17 anos, tem hoje o direito de aposentar-se pelo atual sistema aos 52 anos. Pelo novo sistema, terá direito à aposentadoria aproximadamente aos 58 anos (60 anos corrigido pelo tempo de serviço, que foi longo). Com quanto tempo aposentaria o funcionário, também admitido aos 17 anos, que no momento da emenda constitucional tivesse completado 17 anos e meio de serviço público? Como se garantirão que as expectativas de direito, sua aposentadoria, calculada através de uma simples regra de 3, ocorrerá em torno dos 55 anos? O mesmo tipo de cálculo deverá ser realizado para se determinar o valor da aposentadoria: deverá ser um valor intermediário entre a aposentadoria integral mais $20 \%$ que hoje prevalece e a aposentadoria em torno de $80 \%$ que caracterizará o novo sistema.

\section{Três projetos fundamentais}

Três outros projetos, além da reforma constitucional que acabei de delinear, são ainda essenciais para a reforma do aparelho do Estado brasileiro: descentralização dos serviços sociais através das "organizações sociais", implementação das atividades exclusivas de Estado através das "agências executivas", e fortalecimento do núcleo estratégico do Estado, através de recrutamento, treinamento e boa remuneração, visando à profissionalização cada vez maior do servidor.

O primeiro projeto é o da descentralização dos serviços sociais do Estado, de um lado para os estados e municípios, de outro, do aparelho do 
Estado propriamente dito para o setor público não-estatal. Esta última reforma se dará através da dramática concessão de autonomia financeira e administrativa às entidades de serviço do Estado, particularmente de serviço social, como as universidades, as escolas técnicas, os hospitais, os museus, os centros de pesquisa, e o próprio sistema da previdência. Para isto, a idéia é criar a possibilidade dessas entidades serem transformadas em "organizações sociais".

O segundo projeto é o das "agências executivas". A necessidade de aumentar o grau de autonomia e a conseqüente responsabilização por resultados inspiraram a formulação deste projeto, que tem como objetivo a transformação de autarquias e de fundações que exercem atividades exclusivas do Estado, em agências com ampla liberdade de gerenciar seus recursos humanos e financeiros, a partir de um orçamento global. O Projeto das Agências Executivas está se desenvolvendo em duas dimensões. Em primeiro lugar, estão sendo elaborados os instrumentos legais necessários à viabilização das transformações pretendidas e um levantamento visando superar os obstáculos na legislação, normas e regulações existentes, concedendo-se gradualmente dispensas de controles burocráticos para elas, e lhes assegurando autonomia administrativa e responsabilidade. Em paralelo, começam a ser aplicadas as novas abordagens em algumas autarquias selecionadas, que se transformarão em laboratórios de experimentação.

Finalmente, o terceiro projeto prioritário é o fortalecimento do núcleo estratégico do Estado, que buscará completar o processo de profissionalização do administrador público. Já existem carreiras relativamente bem estruturadas de militares, policiais, juízes, promotores, procuradores, fiscais e diplomatas. Não está clara a existência de uma carreira de altos administradores públicos. A idéia é desenvolver essa carreira a partir das carreiras já existentes, criadas no final dos anos 80 , de gestores governamentais, de analistas de finanças e controle, e de analistas do Orçamento. Já foram dados os primeiros passos nessa direção através da previsão de concursos públicos anuais para essas carreiras, com datas de inscrição e número de vagas definidos até 1999. Os concursos exigirão nível de conhecimento de pós-graduação em administração pública ou em economia. Os altos administradores destinar-se-ão a ocupar os cargos superiores de todos os setores da administração pública, onde necessitam-se de administradores generalistas, administradores financeiros e de controle, e de administradores do orçamento e programação econômica. Seu recrutamento se dará principalmente nos cursos de mestrado profissional em administração pública, economia e ciência política. 


\section{Conclusão: perspectivas da Reforma}

Esta proposta de reforma do aparelho do Estado consubstanciou-se no Plano Diretor da Reforma do Estado, preparado pelo Ministério da Administração Federal e Reforma do Estado, aprovado em setembro de 1995 pela Câmara da Reforma do Estado ${ }^{28}$ (Ministério da Administração Federal e Reforma do Estado, 1995). Enquanto isto, em julho de 1995 o governo enviou sua proposta de emenda constitucional, que em outubro desse mesmo ano foi aprovada na Comissão de Justiça com pequenas modificações. No final do ano foi nomeado o relator da emenda, que terminou três meses depois seu relatório, mantendo a maioria das propostas do governo, aperfeiçoando alguns aspectos, e deixando em suspenso o tema mais difícil: a mudança na estabilidade dos servidores. Até abril de 1997, entretanto, a reforma administrativa não pôde ser votada, dadas as dificuldades que enfrentou o governo na aprovação da reforma da previdência social e a inviabilidade prática de votar duas emendas dessa dimensão ao mesmo tempo. Os revezes sofridos pelo governo na emenda da previdência o enfraqueceram politicamente e faziam prever dificuldades grandes para a emenda administrativa no momento de sua votação, apesar do forte apoio que essa emenda recebia da opinião pública e dos governadores dos estados.

Por outro lado, naquilo que não se chocava diretamente com a Constituição, as idéias relativas à redução dos custos da administração federal, ao fortalecimento do núcleo estratégico, à implantação de agências executivas e das organizações sociais, caminhava, tanto em nível federal quanto em nível dos estados e municípios, onde a explosão dos custos com pessoal pressionava por reforma. Os estados, especialmente, passaram a tomar diversas medidas para coibir a existência de "marajás", principalmente entre os aposentados da Polícia Militar e do Poder Judiciário. E iniciaram programas de demissão voluntária, enquanto esperavam a reforma constitucional.

Em nível federal, em relação às organizações sociais, tornou-se claro, desde meados de 1995, que não seria possível implantá-las nas universidades federais, dada a resistência dos professores e funcionários, que identificaram a publicização proposta com um processo de privatização. $\mathrm{Na}$ verdade, a resistência à mudança nessa área está ligada à concepção burocrática do Estado brasileiro ainda prevalecente em nossas elites segundo a qual certas instituições que prestam serviços fundamentais ao Estado e por ele são pagas, como é o caso das universidades federais, devem ter o monopólio das receitas do Estado naquele setor - no caso, o monopólio dos recursos destinados ao ensino e à pesquisa. Enquanto esse tipo de cultura burocrática não for mudada, enquanto não houver o amplo entendimento de que quem presta serviço ao Estado deve fazê-lo 
de forma eficiente e competitiva, será difícil transformar o Estado brasileiro em uma instituição realmente democrática a serviço dos cidadãos, e não em uma organização a serviço dos funcionários e capitalistas que têm poder suficiente para privatizá-lo.

Quase dois anos depois de iniciada, posso afirmar hoje que as perspectivas em relação à reforma da administração pública são muito favoráveis. Quando o problema foi colocado pelo novo governo, no início de 1995, a reação inicial da sociedade foi de descrença, senão de irritação. Na verdade, caiu uma tempestade sobre mim. A imprensa adotou uma atitude cética, senão abertamente agressiva. Várias pessoas sugeriram-me que "deveria falar menos e fazer mais", como se fosse possível mudar a Constituição sem antes realizar um amplo debate. Atribuí essa reação à natural resistência ao novo. Estava propondo um tema novo para o País. Um tema que jamais havia sido discutido amplamente. Que não fora objeto de discussão pública na Constituinte. Que não se definira como problema nacional na campanha presidencial de 1994. Que só constava marginalmente dos programas de governo. Em síntese, que não estava na agenda do País. ${ }^{29}$

À resistência ao novo, entretanto, deve ter-se somado um segundo fator. Segundo Przeworski (1995), o êxito da reforma do Estado depende da capacidade de cobrança dos cidadãos. Ora, a cultura política no Brasil sempre foi antes autoritária do que democrática. Historicamente o Estado não era visto como um órgão ao lado da sociedade, oriundo de um contrato social, mas como uma entidade acima da sociedade. Desta forma, conforme observa Luciano Martins (1995a: 35), "a responsabilidade política pela administração dos recursos públicos foi raramente exigida como um direito de cidadania. Na verdade, o princípio de que não há tributação sem representação é completamente estranho à cultura política brasileira". Não constitui surpresa, portanto, que a reação inicial às propostas, quando elas estavam ainda sendo formuladas, foi tão negativa.

Entretanto, depois de alguns meses de insistência por parte do governo, começaram a surgir os apoios: dos governadores, dos prefeitos, da imprensa, da opinião pública e da alta administração pública. No final de 1996 havia uma convicção não apenas de que a reforma constitucional tinha ampla condição de ser aprovada pelo Congresso, como também que era fundamental para o ajuste fiscal dos estados e municípios, além de essencial para se promover a transição de uma administração pública burocrática, lenta e ineficiente, para uma administração pública gerencial, descentralizada, eficiente, voltada para o atendimento aos cidadãos. A resistência à reforma localizava-se agora apenas em dois extremos: de um lado, nos setores médios e baixos do funcionalismo, nos seus representantes corporativos sindicais e partidários, que se julgam de esquerda; 
de outro lado, no clientelismo patrimonialista ainda vivo, que temia pela sorte dos seus beneficiários, muitos dos quais são cabos eleitorais ou familiares dos políticos de direita.

Fundamental, no processo de reforma, é o apoio da alta burocracia — um apoio que está sendo obtido. Na Inglaterra, por exemplo, a reforma só se tornou possível quando a alta administração pública britânica decidiu que estava na hora de reformar, e que para isto uma aliança estratégica com o Partido Conservador, que assumira o governo em 1979, era conveniente. Mais amplamente, é fundamental o apoio das elites modernizantes do país, que necessariamente inclui a alta administração pública. Conforme observa Piquet Carneiro (1993: 150): nas duas reformas administrativas federais (1936 e 1967), "esteve presente a ação decisiva de uma elite de administradores, economistas e políticos — autoritários ou não — afinados com o tema da modernização do Estado, e entre eles prevaleceu o diagnóstico comum de que as estruturas existentes eram insuficientes para institucionalizar o processo de reforma".

Depois de um período natural de desconfiança para as novas idéias, este apoio vem ocorrendo sob as mais diversas formas. Ele parte da convicção generalizada de que o modelo implantado em 1988 foi irrealista, tendo agravado ao invés de resolver o problema. O grande inimigo não é apenas o patrimonialismo, mas também o burocratismo. O objetivo de instalar uma administração pública burocrática no país continua vivo, já que jamais se logrou completar essa tarefa; mas tornou-se claro em 1995 que, para isto, é necessário dar um passo além e caminhar em direção à administração pública gerencial, que engloba e flexibiliza os princípios burocráticos clássicos. Uma enquete feita recentemente entre as elites brasileiras apontou um forte apoio à reforma, particularmente entre os empresários e os altos administradores públicos (IBEP, 1997). Assim, apesar das dificuldades que a reforma vêm enfrentando, seja no Congresso, seja na sua efetiva implementação na administração, existem boas razões para pensarmos em perspectivas otimistas. Na verdade, uma reforma gerencial é um processo em andamento atualmente no Brasil. 
1 Texto apresentado no Congresso da Associação Internacional de Ciência Política IPSA, Seul, Agosto, 1997. Publicado in Revista da ANPEC.

2 Conforme observou Fernando Henrique Cardoso (1996: A10), "a globalização modificou o papel do Estado... a ênfase da intervenção governamental agora dirigida quase exclusivamente para tornar possível às economias nacionais desenvolverem e sustentarem condições estruturais de competitividade em escala global".

3 Para uma crítica do conceito de governabilidade relacionado com o equilíbrio entre as demandas sobre o governo e sua capacidade de atendê-las, que tem origem em Huntington (1968), ver Diniz (1995).

4 Está claro para nós que, conforme observa Frischtak (1994: 163), "o desafio crucial reside na obtenção daquela forma específica de articulação da máquina do Estado com a sociedade na qual se reconheça que o problema da administração eficiente não pode ser dissociado do problema político". Não centraremos, entretanto, nossa atenção nessa articulação.

5 A expressão organização não-governamental (ONG) poderia ser considerada sinônimo de organização pública não-estatal (OPNE). OPNE seria apenas uma forma mais precisa de referir-se às entidades do terceiro setor sem fins lucrativos, na qual (1) não se confunde Estado com governo, e (2) se enfatiza o caráter público, voltado para o interesse de todos, desse tipo de organização voluntária. Na prática, as ONGs pretendem ser e são uma forma "mais moderna" de ação principalmente nas áreas da educação, da saúde, do meio ambiente e da assistência social, não incluindo nem pequenas instituições assistenciais, nem grandes fundações, as quais, todavia, são também OPNEs.

6 Esta foi uma forma equivocada de entender o que é a administração pública gerencial. A contração da burocracia através das empresas estatais impediu a criação de corpos burocráticos estáveis dotados de uma carreira flexível e mais rápida do que as carreiras tradicionais, mas sempre uma carreira. Conforme observa Santos (1995), "assumiu o papel de agente da burocracia estatal um grupo de técnicos, de origens e formações heterogêneas, mais comumente identificados com a chamada tecnocracia que vicejou, em especial, na década de 70. Oriundos do meio acadêmico, do setor privado, das (próprias) empresas estatais, e de órgãos do governo - esta tecnocracia... supriu a administração federal de quadros para a alta administração". Sobre essa tecnocracia estatal ver os trabalhos clássicos de Martins (1973, 1985) e Nunes (1984).

7 Nas palavras de Nilson Holanda (1993: 165): “A capacidade gerencial do Estado brasileiro nunca está tão fragilizada; a evolução nos últimos anos, e especialmente a partir da chamada Nova República, tem sido no sentido de uma progressiva piora da situação; e não existe, dentro ou fora do governo, nenhuma proposta condizente com o objetivo de reverter, a curto ou médio prazo, essa tendência de involução".

8 Constitui exceção a essa generalização a reforma do sistema financeiro nacional realizada entre 1983 e 1988, com o fim da "conta-movimento" do Banco do Brasil, a criação da Secretaria do Tesouro, a eliminação de orçamentos paralelos, especialmente do "orçamento monetário" e a implantação de um excelente acompanhamento e controle computadorizado do sistema de despesas: o SIAFI (Sistema Integrado de Administração Financeira). Estas reformas, realizadas por um notável grupo de burocratas liderados por Mailson da Nóbrega, João Batista Abreu, Andréa Calabi e Pedro Parente, estão descritas em Gouvêa (1994). 
9 Mais precisamente em 1936 foi criado o Conselho Federal do Serviço Público Civil, que, em 1938, foi substituído pelo DASP. Esta reforma foi promovida por Maurício Nabuco e Luiz Simões Lopes no primeiro governo Vargas.

10 O DASP foi extinto em 1986, dando lugar à SEDAP - Secretaria de Administração Pública da Presidência da República — que, em janeiro de 1989, é extinta, sendo incorporada na Secretaria do Planejamento da Presidência da República. Em março de 1990 é criada a SAF - Secretaria da Administração Federal da Presidência da República, que, entre abril e dezembro de 1992, foi incorporada ao Ministério do Trabalho. Em janeiro de 1995, com o início do governo Fernando Henrique Cardoso, a SAF transforma-se em MARE - Ministério da Administração Federal e Reforma do Estado.

11 Beltrão participou da reforma administrativa de 1967 e depois, como ministro da Desburocratização, entre 1979 e 1983, transformou-se em um arauto das novas idéias. Definiu seu Programa Nacional de Desburocratização, lançado em 1979, como uma proposta política visando, através da administração pública, "retirar o usuário da condição colonial de súdito para investi-lo na de cidadão, destinatário de toda a atividade do Estado" (Beltrão, 1984: 11).

12 Conforme Bertero (1985: 17), "subjacente à decisão de expandir a administração pública através da administração indireta, está o reconhecimento de que a administração direta não havia sido capaz de responder com agilidade, flexibilidade, presteza e criatividade às demandas e pressões de um Estado que se decidira desenvolvimentista".

13 Esta aliança recebeu diversas denominações e conceituações nos anos 70. 'Fernando Henrique Cardoso referiu-se a ela através do conceito de "anéis burocráticos"; Guillermo O’Donnell interpretou-a através do "regime burocrático autoritário"; eu me referi sempre ao "modelo tecnoburocrático-capitalista"; Peter Evans consagrou o conceito de "tríplice aliança".

14 Não obstante o Decreto-Lei 200 contivesse referências à formação de altos administradores (art.94,V) e à criação de um Centro de Aperfeiçoamento do DASP (art.121).

$15 \mathrm{O}$ regime militar sempre procurou evitar esses dois males. De um modo geral, logrou seu intento. $\mathrm{O}$ fisiologismo ou clientelismo, através do qual se expressa modernamente o patrimonialismo, existia na administração central no período militar, mas era antes a exceção do que a regra. Este quadro muda com a transição democrática. Os dois partidos vitoriosos - o PMDB e o PFL — fazem um verdadeiro loteamento dos cargos públicos. A direção das empresas estatais, que tendia antes a permanecer nas mãos dos técnicos, é também submetida aos interesses políticos dominantes.

16 Estes privilégios, entretanto, não surgiram por acaso: fazem parte da herança patrimonialista herdada pelo Brasil de Portugal. Conforme observa Luiz Nassif (1996): "A análise da formação econômica brasileira mostra que uma das piores pragas da herança colonial portuguesa foi o sonho da segurança absoluta, que se entranhou profundamente na cultura social brasileira. No plano das pessoas físicas, a manifestação máxima dessa síndrome foi o sonho da aposentadoria precoce e do emprego público".

${ }^{17} \mathrm{Na}$ verdade, a Constituição exigiu apenas a instituição de Regime Jurídico Único. A lei definiu que este regime único seria estatutário. Em alguns municípios a lei definiu para regime único o regime celetista. A Constituição, além disso, no art. 19 do ADCT, quando conferiu estabilidade a celetistas com mais de cinco anos, não os transformou em ocupantes de cargos públicos. Bem ao contrário, exigiu, para que fossem os mesmos instalados em cargos públicos, que prestassem "concurso de efetivação". Neste concurso de efetivação, o tempo de serviço seria contado como "título". O STF tem concedido liminares sustando a eficácia a leis estaduais que repetiram o modelo da lei federal que transformou celetistas em estatutários "de chofre". Até o momento ninguém, porém se dispôs a argüir a inconstitucionalidade da lei 8.112, um monumento ao corporativismo.

18 Conforme observa Pimenta (1994: 161): "O papel principal da SAF no período estudado foi o de garantir o processo de fortalecimento e expansão da administração 
direta e defender os interesses corporativistas do funcionalismo, seja influenciando a elaboração da nova Constituição, seja garantindo a implantação do que foi determinado em 1988".

19 Sobre a competência e o espírito público da alta burocracia brasileira ver Schneider (1994) e Gouvêa (1994).

20 A primeira experiência importante e bem-sucedida de demissão voluntária no serviço público brasileiro ocorreu no Banco do Brasil em 1995. O banco possuía 130 mil funcionários. Apontou 50 mil como passíveis de demissão e ofereceu indenização para que cerca de 15 mil funcionários se demitissem voluntariamente. Depois de uma agitada intervenção dos sindicatos, obtendo liminares em juízes de primeira instância imbuídos de espírito burocrático, a política foi declarada legal. Apresentaram-se 16 mil para a demissão voluntária. Em alguns estados, particularmente no Rio Grande do Sul, programas similares obtiveram sucesso reduzindo entre 2 e $4 \%$ o número de funcionários públicos estaduais. O programa federal promoveu redução de $3 \%$.

21 Segundo Pimenta (1994: 154): “A institucionalização da função-administração no governo federal ocorre durante todo o período republicano brasileiro de forma cíclica... O Brasil viveu um processo de centralização organizacional no setor público nas décadas de 30 a 50, com o predomínio da administração direta e de funcionários estatutários. Já nas décadas de 60 a 80 ocorreu um processo de descentralização, através da expansão da administração indireta e da contratação de funcionários celetistas. O momento iniciado com a Constituição de 1988 indica a intenção de se centralizar novamente (Regime Jurídico Único — estatutário)".

22 A expressão "agência autônoma" talvez seja mais adequada para um órgão intermediário entre as agências executivas e as organizações sociais: as agências reguladoras, que exercem atividade exclusiva de Estado, mas devem ter conselhos de direção com mandato, dotados de uma autonomia maior do que o das agências executivas. Enquanto estas devem seguir a política definida pelo governo, as agências reguladoras, quando definem preço, não devem seguir uma política governamental que varia com o tempo e as circunstâncias: seu papel permanente é de estabelecer o preço que seria o do mercado, se mercado competitivo houvesse.

23 Conforme observa Bandeira de Mello,(1975: 14) para o jurista ser propriedade privada ou pública não é apenas um título, é a submissão a um específico regime jurídico: um regime de equilíbrio comutativo entre iguais (regime privado) ou a um regime de supremacia unilateral, caracterizado pelo exercício de prerrogativas especiais de autoridade e contenções especiais ao exercício das ditas prerrogativas (regime público). "Saber se uma atividade é pública ou privada é mera questão de indagar do regime jurídico a que se submete. Se o regime que a lei lhe atribui é público, a atividade é pública; se o regime é de direito privado, privada se reputará a atividade, seja, ou não, desenvolvida pelo Estado. Em suma: não é o sujeito da atividade, nem a natureza dela que lhe outorgam caráter público ou privado, mas o regime a que, por lei, for submetida". Estou reconhecendo este fato ao considerar a propriedade pública não-estatal como regida pelo direito privado; ela é pública do ponto de vista dos seus objetivos, mas privada sob o ângulo jurídico.

24 Direito Administrativo é o ramo do Direito que organiza e disciplina o Estado. É o Direito "burocrático" da burocracia. No Brasil, bem como nos países que herdaram as tradições jurídicas romana e napoleônica, é um ramo da Lei muito desenvolvido.

25 Essas instituições são impropriamente chamadas de "organizações não-governamentais" ou entidades sem fins lucrativos, na medida em que os cientistas políticos nos Estados Unidos geralmente confundem governo com Estado. É mais correto falar em organizações não-estatais, ou, mais explicitamente, públicas não-estatais. 
26 "São ou devem ser" porque uma entidade formalmente pública, sem fins lucrativos, pode, na verdade, sê-lo. Nesse caso trata-se de uma falsa entidade pública. São comuns casos desse tipo, particularmente na área das universidades e hospitais.

27 Já que estas instituições eram reguladas pelo Decreto-Lei 200, estabelecido pelo Estado, depois da Constituição de 88 elas ficaram submetidas a todas as restrições administrativas da administração estatal.

28 A Câmara da Reforma do Estado é formada pelos ministros da Administração, da Fazenda, do Planejamento, do Trabalho, pelo Estado Maior das Forças Armadas, sob a coordenação do chefe da Casa Civil da Presidência.

29 Para ser mais preciso, itens como a revisão da estabilidade do servidor constavam das propostas de emenda constitucional do governo Collor; foram produto, em grande parte, do trabalho de setores esclarecidos da burocracia preocupados em dotar aquele governo de um programa melhor estruturado na sua segunda fase, após ampla reestruturação ministerial. 
Abrucio, Fernando L. "Profissionalização". In: Andrade e Jacoud, orgs. (1993).

ANDRADE, R. e L. JACOUD, orgs. Estrutura e Organização do Poder Executivo - Volume 2. Brasília: Escola Nacional de Administração Pública - ENAP, 1993.

ANDRADE, Régis. "Introdução". In: Andrade e Jacoud, orgs. (1993).

Associação Nacional de Especialistas em Políticas Públicas e Gestão Governamental . "Reforma do Estado e Administração Pública: diagnósticos e propostas para o novo governo". Mimeo, outubro 1994, versão 2.

Bandeira de Mello, Celso Antônio. Prestação de Serviços Públicos e Administração Indireta. Revista dos Tribunais, São Paulo, 1975.

BARZELAY, Michael. Breaking through bureaucracy. Berkeley: University of California Press, 1992.

Beltrão, Hélio. Descentralização e liberdade. Rio de Janeiro: Record, 1984.

Bertero, Carlos Osmar. Administração Pública e Administradores. Brasília: Funcep, 1985.

Bresser Pereira, Luiz Carlos. "Contra a corrente: a experiência no Ministério da Fazenda". Revista Brasileira de Ciências Sociais, n.19, julho 1992. Testemunho ao Instituto Universitário de Pesquisas do Rio de Janeiro (apresentado em setembro de 1988).

Bresser Pereira, Luiz Carlos. "De Volta ao Capital Mercantil: Caio Prado Jr. e a Crise da Nova República”. Revista Brasileira de Ciência Política 1(1), março 1989. Também em Maria Angela D'Incao, História e Ideal: Ensaios sobre Caio Prado Jr.. São Paulo, Brasiliense, 1989.

CARDoso, Fernando Henrique. "Globalização". Conferência pronunciada em Nova Delhi, Indía, janeiro 1966. Publicada em O Estado de S.Paulo, 28 de janeiro, 1996.

CaValcanti de Albuquerque, Roberto. "Reconstrução e Reforma do Estado”. In: Velloso e Cavalcanti de Albuquerque, orgs. (1995).

Cunil Grau, Nuria. "La Rearticulación de las Relaciones Estado-Sociedad: en Busqueda de Nuevos Sentidos". Revista del Clad - Reforma y Democracia, no.4, julho 1995.

DinIz, Eli. "Governabilidade, Democracia e Reforma do Estado: Os Desafios da Construção de uma Nova Ordem no Brasil dos Anos 90”. Dados 38(3), 1995.

FaIrbrother, Peter. Politics and the State as Employer. Londres: Mansell, 1994.

FRISCHTAK, Leila L. "Governance Capacity and Economic Reform in Developing Countries". Technical Paper no.254. World Bank: Washington, 1994.

Genro, Tarso. “A Esquerda e um Novo Estado”. Folha de S. Paulo, 7 de janeiro, 1996.

GouvÊA, Gilda Portugal. Burocracia e Elites Dominantes do País. São Paulo: Paulicéia, 1994.

Graef, Aldino. "Nova Fase do Capitalismo de Estado". Cadernos ENAP 2(4), dezembro 1994: Reforma do Estado, 1994.

Gurgel, Cláudio. "Reforma do Estado: Weber e a Estabilidade". Archétipon, 4(10), 1995 (Rio de Janeiro: Faculdades Cândido Mendes), 1995.

Holanda, Nilson. "A Crise Gerencial do Estado Brasileiro". In: João Paulo Reis Velloso, org. (1993). Brasil: a superação da crise. São Paulo: Nobel, 1993.

Huntington, Samuel P. Political order in changing societies. New Haven: Yale University Press, 1968.

IBEP. Os formadores de opinião e a reforma do Estado. Brasília: IBEP - Instituto Brasileiro de Estudos Políticos, Relatório de Pesquisa, janeiro 1997.

KetL, D. and J. Dilulio. Inside the Reinvention Machine: Appraising Governmental Reform. Washington: The Brookings Institution, Center for Public Management, 1994. 
Ketl, Donald F. Reinventing Government? Appraising the National Performance Review.Washington: The Brookings Institution, Center for Public Management, agosto 1994.

Marcelino, Gileno Fernandes. Evolução do Estado e Reforma Administrativa. Brasília: Imprensa Nacional, 1987.

Martins, Luciano. Pouvoir et Développement Economique. Paris: Editions Anthropos, 1976. Tese de doutorado de Estado. Universidade de Paris V, 1973.

Martins, Luciano. Estado Capitalista e Burocracia no Brasil Pós-64. Rio de Janeiro: Paz e Terra, 1985.

Ministério da Administração Federal e Reforma do Estado. Plano Diretor da Reforma do Estado. Brasília: Presidência da República, Imprensa Oficial, novembro 1995.

Ministério da Fazenda. Plano de Controle Macroeconômico. Brasília: Ministério da Fazenda, Secretaria Especial de Assuntos Econômicos, julho 1987.

NAssif, Luís. "O Brasil e o mito da segurança”. Folha de S. Paulo, 7 de janeiro, 1996.

Nunes, Edson de Oliveira. Bureaucratic Insulation and Clientelism in Contempory Brazil: Uneven State Building and the Taming of Modernity. Ph.D. dissertation, Department of Political Science, University of Berkeley. Traduzido como A Gramática Política do Brasil. Rio de Janeiro e Brasília: Zahar Editores e Escola Nacional de Administração, 1997.

Osborne, D. e T. Gaebler. Reinventing Government. Reading, Mass.: Addison-Wesley, 1992.

OsLaK, Oscar. "As demandas de formação de administradores públicos frente ao novo perfil do Estado”. Revista do Serviço Público, ano 46, vol.119, n.1, janeiro 1995.

Pimenta, Carlos César. "Aspectos recentes da organização e das políticas de modernização da função pública federal". Rio de Janeiro: Revista de Administração Pública, 28(2), abril 1994.

Piquet CARneiro, João Geraldo. "Requisitos políticos e técnicos da reforma do Estado". In João Paulo Reis Velloso, org. (1993).

Przeworski, Adam. “O que os países civilizados têm em comum”. Folha de S. Paulo, 2 de abril, 1995.

Przeworski, Adam. "Reforming the State: Political Accountability and Economic Intervention". Mimeo. Trabalho apresentado à conferência "Inequality, the Welfare State and Social Values”, El Escorial, Espanha, julho 1995.

Przeworski, Adam, Pranab Bardham, Luiz Carlos Bresser Pereira et alli. Sustainable Democracy. Cambridge: Cambridge University Press, 1995.

PrZworski, Adam. "Reforma do Estado: Responsabilidade Política e Intervenção Econômica”. Revista Brasileira de Ciências Sociais, 32(11) outubro 1996.

SAntos, Luiz Alberto. "Modelo Brasileiro para a Organização da Alta Administração". Brasília: Revista do Serviço Público, 119(2) maio 1995.

SchneIder, Ben Ross. Burocracia Pública e Política Industrial no Brasil. São Paulo: Editora Sumaré, 1994.

SCHNEIDER, Ben Ross. "A conexão da carreira: uma análise comparativa de preferências e Insulamento Burocrático”. Revista do Serviço Público, ano 46, vol.119, n.1, janeiro 1995.

Weber, Max. Economy and Society. Berkeley: University of California Press, 1978. First German edition, 1922.

Weber, Max. "Origen del Estado Racional". Chapter 4, Section 8 of Wirtschaftsgeschchte: Abris der Univerwsalen Sozial- und Wirtschaftsgerchichte. Published as an Appendix IX (pp. 1047-1056) to the Spanish translation of Economy and Society, Mexico City, Fondo de Cultura Económica, 1964. First German edition, 1923. 
Revista do

Serviço

Público

Ano 49

Número 1

Jan-Mar 1998

Ministro da

Administração

Federal e

Reforma do

Estado e

professor da

Fundação

Getúlio Vargas,

São Paulo

\section{Uma reforma gerencial da Administração Pública no Brasil}

Luiz Carlos Bresser Pereira

O texto aborda as principais características da reforma administrativa em andamento no Brasil. A proposta é de mudança da administração pública burocrática e clientelista para uma administração pública gerencial, baseada no enfoque da "nova administração pública". A reforma brasileira distingue as atividades exclusivas do Estado, detentoras do poder de Estado, dos serviços sociais e científicos e das empresas estatais. O primeiro setor permanecerá dentro do aparato estatal e as empresas estatais estão sendo privatizadas. Com relação aos serviços sociais e científicos, que recebem um suporte substancial do Estado, a proposta é de transformá-los em organizações sociais não lucrativas, seguindo as linhas dos "quangos" (quasi non governamental organizations) ingleses.

\section{Una reforma de la Administración Pública en Brasil \\ Luiz Carlos Bresser Pereira}

El texto trata de las principales características de la reforma administrativa en curso en Brasil. Se propone un cambio de la administración pública burocrática y clientelista para una administración pública gerencial, basada en el enfoque de la "nueva administración pública". La reforma brasileña distingue las actividades exclusivas del Estado, detenedoras del poder de Estado, de los servicios sociales y científicos y de las empresas estatales. El primer sector permanecerá dentro del aparato estatal; las empresas estatales siguen siendo privatizadas. Con respecto los servicios sociales y científicos, que reciben un sustancial soporte del Estado, se propone transformarlos en organizaciones sociales no lucrativas, siguiendo las mismas líneas de los "quangos" (quasi non governmental organizations) ingleses.

\section{Managerial reform in Brazil's Public Administration}

\section{Luiz Carlos Bresser Pereira}

This paper points out the main features of the current administrative reform in Brazil. The proposal is to change from a bureaucratic and clientelistic to a managerial public administration, that follows the "new public administration" approach. The Brazilian reform distinguishes the exclusive activities of the state, where state power is involved, from the social and scientific services, and the state-owned enterprises. The first sector will remain within the state apparatus and the state-owned enterprises are being privatized. As to the social and scientific services, that are supposed to receive a substantial support of the state, the proposal is to transform them into non-profit organizations, folowing the lines of the British quangos (quasi non-governmental organizations). 